\title{
It Is Not Yet 'Uhuru': Overcoming the Challenges of Citizenship and Nationality Questions in Post-Separation Sudan and South Sudan
}

\author{
Ferdinand O. Ottoh \& Solomon O. Akinboye \\ Department of Political Science \\ University of Lagos, Akoka, Lagos, Nigeria \\ vonferd@yahoo.com; ottohvonferd@gmail.com; \\ solomon_akinboye@yahoo.com \\ DOI: https://doi.org/10.32890/jis2016.12.6
}

Abstract

\begin{abstract}
This paper focuses on the nationality and citizenship crisis in post-separation Sudan. The paper argues that the unresolved issues in the agreement, especially the issue of nationality and citizenship are serious threats to the stability of the new state of South Sudan. Both North Sudan and South Sudan have demonstrated a lack of political will to resolve the nationality and citizenship problem. This explains why they were not able to adopt a common legal framework that will help to address the age-long problem instead of each adopting new nationality laws. The paper adopts the historical and institutional-legalistic approach in the discourse to situate the problem. It argues therefore, that the citizenship problem will continue in a system that is stratified along ethnic/racial and religious lines as epitomized in Sudan. We conclude that it is the resolution of outstanding issues of nationality and citizenship question that will help to sharpen the pattern of state-ethnic relations in the separated countries of north and south Sudan. With independence granted to Southern Sudan, the crisis of citizenship remains both in the north and the south.
\end{abstract}

Keywords: Citizenship, national identity, multiculturalism, national question, nationality, Jus soli and Jus sanguinis, state-building and nation-building.

\section{Introduction}

There is the need to turn to history for the nationality and citizenship question in Sudan with the view to understand the current situation in the post-separation era. It is imperative to situate the crisis of citizenship and nationality in their historical, sociological and anthropological contexts. Historically, the migration of people in pre-colonial Africa, the tribal system of power with its attendant consequence of citizenship law has continued to affect some groups in some plural societies in Africa. In Africa, people migrate to the centre of political power for the purpose of power consolidation. There is a general believe that being closer to the centre of political power gives much needed impetus to political participation. 
The movement of people from one place to the another is essentially for economic reasons and to free themselves from the oppressive and brutal rule of their leaders although the fragmentation of Africa ended many traditional patterns of migration that had been under threat during the colonial era. The thesis is that the changing patterns of migration and the dynamics of citizenship laws reflect the abilities of African states to consolidate power within their territories (Herbst, 2000). Colonialism fundamentally changed the nature of population movements across the continent. As a result of this, citizenship has acquired a salience that is often greater than the ties between the ethnic groups separated by boundaries. The problem of establishing strong national bonds between the state and the citizens arise because of the lack of regulations. However, citizenship laws in Africa are intended to create a sense of nationhood in a territory that is not politically united. In this regard, defective citizenship laws in Africa made many people to owe allegiance to their ethnic origin rather to their state; ethnic identity becomes stronger than national citizenship. This was the situation in Sudan before and after the separation of South Sudan from Sudan.

The state formation process in the old Sudan underscored the crisis in the Western Darfur region and the age-long conflict in the South which has persisted even after separation. Modern Sudan was an artificial creation with the British conquest in 1898. Before the British conquest, the territory was the eastern reaches of what medieval Arabs called bilad al Sudan (the land of the black people), a broad band that extended through central Africa (Lesch, 1998). The incursion of the Arabs into North Africa was a gradual and systematic process of acculturation and devalurization of their culture. It marked the replacement of African cultural institutions with Arabic ones. This was very glaring in the case of the Berbers/Tamasheq in Morocco, Algeria, Tunisia and Libya. The culture of the Berbers/ Tamasheq and the language of the people suffered subjugation and denigration from the very early history of the Arab/African encounter (Prah, 2001).

Looking at the complex history of identity formation in Sudan with particular reference to Darfur, the British conquest of Darfur in 1916, and the incorporation of the then independent sultanate of Dar Masalit in 1992, represented a return to the past. The incorporation of Darfur into the national Sudanese process polarized the Arabs and the Africans. This explains why it is alluded that organic citizenship was destroyed while ethnic citizenship was promoted as was constructed by the colonial rule. Citizenship as a social category was promoted by the colonial rule and reinforced by post-colonial regimes through various constitutions and policies. To this end, there was an ideological construction of these polarized identities which has resulted in the militarization of Darfur.

Indeed, from the inception the Arabs elevated themselves to the effigy of superiority over the black Sudanese. The mission of the Arabs was to Islamize and civilize the black Africans whom they considered as potential slaves and an inferior race. To this extent, many black Africans in the north were converted to Islam because of the superiority which the Arabs claimed they had over the blacks. These are the basis for the nationality and citizenship crisis. 
The Transitional Constitution of 1956 of Sudan did not address these issues. However, the Nationality Act of 1957 enacted by the parliament replaced the 1948 Ordinance (Manby, 2012). This 1957 parliamentary Act remained in effect until 1993. In 1994, the Transitional National Assembly enacted another Nationality Act which remained in force until the Comprehensive Peace Agreement of 2005 that brought to an end decades of war which followed another Nationality law in 2011 after the separation of South Sudan. It provided that a person was Sudanese if he was born in Sudan or his father was born in Sudan and he or his direct ancestors had been residents in Sudan since 31 December 1897. Subsequently, there was an amendment to this provision in 1924 when Sudan was reorganized administratively into two provinces (Manby, 2012). In this regard, naturalization was based on the conditions of a 10-year residence, adequate knowledge of Arabic, and renunciation of any other nationality. The member of years of residence required for naturalization was reduced to 5 years based on the decree of 1993 and the removal of dual citizenship; in 1994 the law included a change to the applicable date for a claim to nationality by birth based on the domicile of a male ancestor from 1924 to 1 January 1956. Woman married to a Sudanese man could be naturalized on the basis of two years of residence in Sudan with her husband (Manby, 2012).

The citizenship law in Sudan is therefore traced through decent irrespective of the location of birth. It means that in order to be a member of the country, it is necessary that such a person must be born in that territory (Herbst, 2000). Herbst (2002) observes that citizenship laws based on jus sanguinis are often designed to retain both a factual and a symbolic level, to keep the people or folk together and to prevent certain groups from becoming citizens even if they were born within the national territory. The practice of jus sanguinis in Sudan is intended to resist wealthy blacks from taking part in the political process, while giving minority Arabs undue advantage. On the contrary, it may be an attempt to exclude individuals and whole groups who are physically located in a state but who cannot claim descent from Arabs ancestors. The change in citizenship laws from jus soli to jus sanguinis was a reflection of the debates over national identity (Herbst 2000). The fact is that the practice of jus sangunis was not an appropriate policy for many African countries in view of the obvious domestic political conflagration and circumstances. It does not actually reflect the nature and characters of the African state. Jus sanguinis is only a convenient policy for leaders who want to keep others from challenging their authority or ruling. Therefore, postindependence governments in Sudan continued to seek means of consolidating power by applying some policies that further polarized the society.

We cannot agree less with those who share the sentiment from the ethnographic and historical point of view that communal violence helps in identity construction. The nonArabs in Darfur who has been displaced and dispossessed have turned to lay claim to their indigenours and residence rights. The sudden realization of 'Africanness' instead of the pretension to cling to Arabs folks has invoked much support both within Africa and outside. Paradoxically, the Darfur non-Arabs who used to be perpetrators of violence against the blacks in southern Sudan are one of the victims of violence of Arab marauders. It is within this historical context that the song of victory cannot be sung now. The event in the next 
ten years will determine if the 'New Sudan' will be seen to be peaceful and stable or not. Therefore, our task is to set certain parameters for overcoming the challenges of citizenship crisis.

\section{Nationality and Citizenship Contextualized}

In an attempt to contextualize nationality and citizenship it is important to differentiate between state-building and nation-building. These two concepts are directly related to the issues of nationality and citizenship. They are the fundamental problems of African States. State-building focuses on economic development and upgrading the capacity of human resources. An effective security apparatus, responsible fiscal policy, efficient service delivery, and general infrastructure (Jok, 2011). It also entails policies aimed at encouraging the growth of the private sector, including foreign investment. Nation-building on the other hand, refers to a national political project that would produce a sense of national unity and collective national identity with an eye to preventing discord along ethnic lines, especially as tribal violence and its on-going destructive legacies remain part of the collective memory among south Sudanese (Jok, 2011).

Just as state-building and nation-building are distinct from each other conceptually, nationality and citizenship are analytically separate (Jamieson, 2002; Assal, 2011). David McCrone and Richard Kiely define the differences as follows:

Nationality and citizenship actually belong to different spheres of meaning and activity. The former is in essence a cultural concept which binds people on the basis of shared identity... while citizenship is a political concept derived from people's relationship to the state. In other words, nation-ness and state-ness need not be, and increasingly are not, aligned (quoted in Jamieson, 2002, p. 518).

These two terms are often used interchangeably but they not synonymous (Assal, 2011). According to Assal (2011), "citizenship is closely linked to the concept of rights defined by international law and national law". Nationality is a more ambiguous term than citizenship and one closely associated with a subjective understanding of the community. It may refer to membership in an ethno-national group that need not be established as an independent state (Assal 2011). Nationality is quite distinct from citizenship as the former connotes the country where an individual was born, while citizenship is the legal status conferred by a state to a citizen.

However, national laws distinguish types of citizenship which could be either by birth or by naturalization. Citizenship at birth, in turn, may be defined as determined by place of birth (jus soli) or by ancestry (jus sanguinis). Countries that adopt the principle of jus sanguinis is based on ancestry or ethnicity. This is practised in most European countries based on the concept of a nation-state, while citizenship right based on the principle of jus soli is 
It Is Not Yet 'Uhuru': Overcoming the Challenges of Citizenship and Nationality Questions in Post-Separation Sudan and South Sudan

determined by birth in a territory of the state. This is practised in the United States (Assal, 2011). In addition to birth and naturalization, citizenship can be acquired through marriage to a person holding the citizenship (jure matrimonii).

Scholars conceptualize citizenship and citizenship rights in different ways. Hendricks (1997) conceptualizes citizenship as a set of rights and obligations for those who are included in the list of members, which is a social role. Citizenship provides entitlements to a group of persons within a given political community. Entitlements are rights conferred on a citizen at any given time. In a more simplistic way, Hendricks (1997) defines citizenship as a legal and emotive tie between the citizen and the state. In this regard, the importance of the individual and the community is emphasized. Citizenship is about reconciling the interest of the individual and the state within a legal framework. It means that it is enjoyed by individuals on the basis of a fundamental equality of condition, which is their membership of the community.

Osaghae (1990) explains that citizenship in the modern state presupposes a one-to-one direct relationship between the individual and the state. This is necessary because for the individual to be able to enjoy the rights and be given duties in return there should be no intermediary group between him and the state. This, Osaghae describes in terms of two principles called "plebiscitarian" principles of citizenship which differs from the functional principle under which the individual has an indirect relationship with the state through the group, which meditates between the two on rights and duties (Osaghae,1990).

Janoski and Gran (2002) explain further that: "At a foundation level, all citizenship rights are legal and political because citizenship rights are legislated by government decision-making bodies, promulgated by executive orders, or enacted and later enforced by legal decisions" (quoted in Pattie et al., 2004). Thus, for analytical purpose we can define citizenship "as a set of norms, values and practices designed to solve collective action problems which involve the recognition by individuals that they have rights and obligations to each other if they wish to solve such problem" (Pattie et.al., 2004).

By historical conjuncture the idea of a political community from antiquity is based on the demands for common good; this common good is seen as a social imagery that is difficult to achieve. Mouffe (1995) argues that it is impossible to achieve any inclusive political system, which in our candid opinion the so-called common goods can never be delivered. This is so in the words of Mouffe; “... since to construct a 'we' it is necessary to distinguish it from 'them' and all forms of consensus are based on acts of exclusion, the condition of possibility of the political community is at the same time the condition of impossibility of its full realization" (quoted in Momoh, 2001).

From this definition it becomes clear that the state is the agent responsible for the transmission of these values and practices rather than the source as some may claim; even though the state has the tendency to promote and inculcate the values of the citizenship. The 'flask' and 'monster' thesis can offer a better explanation of citizenship crisis in Sudan. This explains the relationship between the state and society. Held (1983) argues that: 
The state maintains compliance or order within a given territory which involves a defence of life, property and the well-being of its citizens... The state web of agencies and institutions finds ultimate sanctions in the claim to the monopoly of coercion and a political order is only in the last instance, vulnerable to crisis when this monopoly erodes. In other words, the state is based on a monopoly of coercion which is legitimized by a belief in the justification and/or legality of this monopoly (quoted in Salih, www.fou.uib.no/fd/1996/f/712001/backevid. htm).

In situating this within a theoretical context, we explore three kinds of pluralisms, the core ones being ethnic, religious and political (Aluko, 2006). The ethnic composition of Sudan is central to the persistent crisis of national identity. This is the reason why most analysis of ethnicity and citizenship are dominated by issues of majority and minority and the relative power differences between the two concepts (Osaghae, 2002; Nnoli, 1978). The distinction between the indigenous and the settlers is in effect a two-tier structure of citizenship rights and opportunities. It borders on the denial of inclusive citizenship rights because of the language, religion and the colour of the skin. The three perspectives of citizenship are: transnational citizenship and possible decline in the nation-state arising from globalization; issues concerning multiculturalism and the growth of a heterogeneous population in many countries; and also feminist perspectives, which challenge traditional theories of citizenship for being male dominated or patriarchal (Pattie et al., 2004).

According to the transnational citizenship perspective, different individuals will have different rights, depending on their status. This simply shows that citizenship rights are no longer tied to national territorial boundaries but embrace all who share the same identity. This means citizenship rights must be separated from the territorial dimension of state membership. Therefore, the multicultural theoretical argument captures essentially the core of this paper. The multicultural perspective centres on how to promote group rights in addition to individual rights, which should enable the minorities to sustain their minority identities and cultures within the wider society. According to Kymlicks (1998), "In a society that recognizes group-differentiated rights, the members of certain groups are incorporated into the political community not only as individuals, but also through the group, and their group membership" (quoted in Pattie et al., 2004).

From this perspective, the argument of globalization and the increasing number of transnational institutions and the agreements thereof have reduced the autonomy of the nation-state in controlling the migration of people. This does not actually explain the situation in Sudan. It is quite true that there were migrant citizens in Sudan, but not on the basis of globalization and trans-nationalism.

The tribal skirmishes between some ethnic groups in South Sudan shows the extent to which the Sudanese state has continued to enjoy the monopoly of the use of force to settle inter-ethnic disputes. In this regard, the existence of ethnic militias among groups in Sudan is a challenge to the state. The post-war Sudan is still confronted with the same problem of 
citizenship identity for either those Arabs residents in South Sudan and the South Sudanese resident in the north. The citizens on both sides of the divide have virtually lost their sense of value to the fact that the only language they understand violence as a form of protest. It is an indication that the state has lost its moral and political will to use force after several years of brutality in a bid to compel obedience among the citizens. This has led to ethnic loyalty to the detriment of national loyalty among the South Sudanese.

\section{It Is Not Yet Uhuru with the Separation of South Sudan}

There is the presumption that the Comprehensive Peace Agreement (CPA) signed on $9^{\text {th }}$ January 2005 between the Central Government of Sudan and the Sudan People's Liberation Army/ Movement (SPLA/M) is to be implemented fully. Unfortunately, barely one year after South Sudan gained independence crisis erupted between the two countries taking them back to the dark old days of crisis. This crisis orchestrated by unresolved issues of citizenship and nationality fundamentally impeded the state-building process in the new Southern Sudan. The outbreak of crisis between the North and the South shortly after the separation shows the dysfunctional and incomplete implementation of the CPA as it pertains to wealth-sharing, border demarcation and management, Abyei crisis, oil revenues, and Nile water-sharing among others. Furthermore, challenges of state-building arise from several inter-communal conflicts, extreme cases of complex political emergencies in countries, insurgencies, complex humanitarian crisis, and a near collapse of the economy.

Arguably, the general euphoria that came with independence vanished in the a twinkling of an eye as there were threats and counter-threats emerging from both Khartoum and Juba regarding these unresolved issues, especially the control of the borders. This paper may not dwell so much on it but it is important to point out that the border issue is contentious in view of the international security implications as both countries accused each other of military threats. There are militia groups in South Sudan that the ruling party-Sudan People's Liberation Movement (SPLM)claimed were supported from Khartoum to overthrow or destabilize the government in Juba (Yousif, \& Rothbart, 2012).

In North Sudan, politics and the political process are still militarized as the elites continued in their endless struggle for power. Naturally, the struggle to inherit the north was expected after the exit of the south. The various political parties, namely the Sudan Communist Party, the Umma National Party and the National Popular Party are in strong opposition to the National Congress Party led by Omar Al-Bashir. However, the elites that control these political parties are very conscious of the cultural and racial implications of power relations in the country (Yoh, 2010). The fact is that the political arrangement in Sudan is dominated by elites from the river side who espouse Islamic and Arabic ideology to institutionalize their hegemony over the rest of the ethnic groups especially the non-Arabs. The marginalized regions namely Nubians in the north, Beja in the east, Darfurians in the west, Nuba in the centre, and Funj in the South East were not comfortable with the dominant political forces. Thus, they did not recognize the authority of the government at the centre 
except for the symbolic purposes of belonging to a geographical territory. In these regions, war has increasingly become a part of life (Jok, 2008). The issues of inclusive political participation and decision-making, accommodation of all ethnic groups and recognition of their cultures have not been addressed. It is by establishing an all inclusive political system that the political bond of different ethnic groups will be achieved. This will help to develop a political community and promote state-building.

The Zaghawa conflicts still linger on as the Rezaigat demand that the Zaghawa be expelled from Rezaigat. This is contrary to the constitution, even though there was a settlement in 1987, the conflict between the two groups has not ended. This is one of the problems the north has to deal with. The Zaghawa have maintained for years that they are entitled to economic resources and political leadership by virtue of being Sudanese (Hassan, \& Ray, 2009). The Rezaigat saw the Zaghawa as becoming wealthy and aspiring for political power in their own tribal enclave (Hassan \& Ray, 2009). The Rezaigat are supported by the central government in Khartoum. Interestingly, both tribes are found in Sudan and neighbouring Chad.

The rights to political inclusion to complement the values and cultures of other groups in Northern Sudan is pursued vigorously. Historical precedent shows that the demand for the recognition of the cultures of others is at the root of the conflict before the separation of the southern Sudan. Thus, it is not just about separation but how the political system should be all inclusive. Arguably, the demand for group rights in the new democratic Sudan faces the risk of destruction when the universalistic values of citizenship culture are not adhered to and guaranteed. The pursuit of an all inclusive and accommodative political system will benefit all groups. The inherent fear by some ethnic groups is that incorporating them into a state that will not guarantee them any means of advancement of their collective interest will not augur well for them. This fear becomes more evident in view of the obvious manifestation of the lack of an inclusive governance structure in Sudan.

The system has entrenched a culture of violence with the rise of ethnic militias that have the potential to destabilize the peace process in the future. The escalating tensions in Jonglei, Malakal and Abyei remain key flashpoints for current and future violence and the response of the national and international actors to the violence being perpetrated there will have a defining influence on the security context of the newly independent state.(Tadesse, 2012). The age-long enmity between the ethnic groups in the south has not disappeared either. For instance, the Humr and Ngok Dinka-Humr animosity has continued in the new independent south Sudan. The issue of tribal militias in the Upper Nile and the militarization of ethnic identity struggle are which is alleged to be sponsored by the state. There is also the possibility that the tribal militias of the large ethnic groups in the south may demand for their own separate state with the granting of independence to the South.

The government in Khartoun has been accused of sponsoring coups in the south to destabilize the government in Juba. The coup attempt in the south and the struggle for the control of the 
It Is Not Yet 'Uhuru': Overcoming the Challenges of Citizenship and Nationality Questions in Post-Separation Sudan and South Sudan

government are clear indications that the crisis is not yet over. It rather reinforces the tribal values. This amounted to putting new wine in old bottles.

\section{The Implications of New Nationality Laws in Sudan and South Sudan}

After the separation of South Sudan from the north, the issue of nationality which has not been addressed by the two countries. Rather they chose to introduce separate nationality laws to determine who would become the citizens of the new Republic of South Sudan and who would remain citizens of the Republic of Sudan. The South Sudan nationality law of 2011 brought ethnic definition into Sudanese nationality law for the first time (Manby, 2012). South Sudan adopted the wording of the 1998 and 2005 Constitutions of the Republic of Sudan that: "Every person born to a Sudanese mother or father shall have an inalienable right to enjoy South Sudanese citizenship and nationality", and this explicitly permits dual nationality (quoted in Manby, 2012). Article 8 of the new South Sudanese Nationality Act was adopted in June 2011, barely one month before independence, provides that:

1. A person born before or after this Act has entered into force shall be considered a South Sudanese National by birth if such person meets any of the following requirements: (a) any parents, grandparents or great grandparents of such a person, or the male of female line, were born in South Sudan or, (b) such a person belongs to one of the indigenous ethnic communities of South Sudan.

2. A person shall be considered a South Sudanese National by birth, if at the time of the coming into force of this Act: (a) he or she been domiciled in South Sudan since 1 January, 1956 or, (b) if any of his or her parents or grandparents, have been domiciled in South Sudan since 1 January, 1956,

3. A person who is or was first found in South Sudan as a deserted infant of unknown parents shall, until the contrary is proved, be deemed to be a South Sudanese National by birth (Manby, 2012).

The law also provides for the acquisition of nationality by naturalization based on 10 years' residence, which is longer than the five years that have been applied in the north since 1994, and other conditions. Article 13 of the South Sudan Nationality Act provides that either a man or a woman married to a South Sudanese national may acquire his or her spouse's nationality after five years' residence in South Sudan. This is contrary to the North Sudan Nationality Act.

The Republic of Sudan National Assembly on 19 July 2011 adopted several amendments to the Sudan Nationality Act of 1994 in relation to the deprivation of nationality of those who become citizens of the Republic of South Sudan. According to Article 10(2) Sudanese nationality shall automatically be revoked if the person has acquired, de jure or de facto, the nationality of South Sudan. In Article 10(3) without prejudice to Section 15, Sudanese nationality shall be revoked where the Sudanese nationality of his responsible father is revoked in accordance with section 10(2) of this Act. The Act specifically states that dual 
nationality with the South Sudan is not allowed, but recognizes other countries which may wish to enjoy dual nationality as provided in the 1994 Nationality Act of Sudan. This is contrary to international norms of non-discrimination of any person on the grounds of national origin. (See Article 2 of the African Charter on Human and Peoples' Rights). Article 7 of the 1994 Act, as amended in 2011 provides the conditions for naturalization which will be based on the possession of a sound mind by a person and who has having a lawful way of earning a living. Essentially, the revisions of the 1994 Act were designed to make it difficult for South Sudanese to naturalize in North Sudan.

The implications of the nationality law in new South Sudan are that nationality is defined on the basis of ethnicity. This is because the law specifies that those whose parents, grandparents or great grandparents who were born in South Sudan, and those whose ancestors have been residents in the territory since 1956. This ethnic definition of nationality in Article 8(1) (b) of the Nationality Act creates serious problems for the border people of South Sudan.

It is difficult to explain or understand which ethnic group (s) should be considered to be their indigenous ethnic communities. This in turn raises the question of being indigenous and settlers that has remained an dominant issue in Africa's nation-building process. This is why most conflicts in Africa are often linked with the problems of national identity and citizenship. For citizens with mixed parentage it is more complex. These people may find it extremely difficult to claim entitlement to South Sudanese nationality and even obtaining relevant documentation (Manby, 2012).

To the Republic of Sudan the implications of the nationality laws are that they remain central to the survivability of northern Sudan. The clause in Article 10(2) of the Nationality Law on the loss of nationality if a person acquires South Sudanese nationality either as 'de jure or de facto' has the tendencies to render some persons stateless. Accordingly, Article 10(3) of the Sudan Nationality Act provides that children are not allowed to hold dual nationality with South Sudan except when they have a Sudanese father and a South Sudanese mother. (Manby, 2012). Surprisingly, Article 16 provides that reinstatement of Sudanese nationality is the discretion of the President of the Republic of Sudan. It is an open-ended provision because it does not specify the conditions for individuals to acquire Sudanese nationality. Furthermore, the government of Sudan states that south Sudan residents in the north must 'regularize their status' in Sudan by 8 April 2012, which was nine months after the $9^{\text {th }}$ July, 2011 referendum. The reason for doing so was wholly unclear. This singular power given to the President may be abused as it has been the case before the separation of South Sudan. If the President does not like the person applying for nationality such a person will be denied such rights. As a demonstration of the north to deny south Sudanese the right of nationality, southerners resident and those employed in the civil service in the north and private sectors have been dismissed; their children have been refused registration in schools, and they were denied treatment in the healthcare clinics (Manby, 2012). However, it is important to point out that an individual state determines its nationality law. Therefore, this particular provision cannot be challenged in court. 
In a nutshell, the amendments to the Nationality Law of 2011 were intended to make some South Sudanese living in the north stateless. It is difficult to obtain documentary evidence of nationality, especially in South Sudan because of the lack of records as it is a new state. Besides, South Sudanese in the north will require nationality documentation in order to obtain residence permits in the Republic of Sudan and without such permits their stay becomes illegal and they are vulnerable to deportation. The application of the new identity card (ID card) law is being used to deprive southerners in the north of their status, especially the loss of employment and access to social services. It is also most paradoxical to state that those parents from the north are confronted with the problem of denial of the so-called inalienable right to Sudanese nationality. They are not able to obtain relevant documentation to prove that they are actually Sudanese. The implication of the denial of documentary evidence to South Sudanese residents in the north is mass exodus of people to the south, dispossession of property, etc.

The future of the south Sudanese in the north who are employed in the national public service, those who are members of the Sudan Armed Forces, the Police, the Prisons, employees in the private sector and displaced persons in the camps on the outskirts of Khartoum is hanging in a precarious balance. The same applies to Northern Sudanese who are scattered all over the South, particularly those who are in the business sector (Yoh, 2010). There is the fear of mass exodus of citizens either from the north to the south or vice versa.

\section{Overcoming the Challenges of Citizenship}

The CPA did not clearly spell out the fate of the South Sudanese living in the north after separation. As there are southerners in the north so also there are northerners in the south. It was estimated that there were about 2 million southerners living in the north (Tadesse, 2012). The issue of residence of the southerners in the north was very clear from the way they voted; with the majority of voters against the north. It is natural that the north would feel unwanted and therefore would not want any southerner to remain in the north. The southerners employed by the various state institutions in the north, particularly in the military and the police force were disengaged from the service.

In accordance with the laws and regulations of each state, nationals of each state shall enjoy in the other states the following freedom: (a) freedom of residence; (b) freedom of movement; (c) freedom to undertake economic activity; and (d) freedom to acquire and dispose of property. The signing of the agreement was slated for 3 April 2012 but hostility broke out between the two countries in the oil-rich border territory of Heglig. (Manby, 2012).

The international law's position on the issue of nationality was very clear. In situations of state succession, where the sovereignty over territory is transferred from one state to another, the concerned states have an obligation in international law to ensure that statelessness is prevented (Manby, 2012). This is the corollary of the right of every individual to a nationality as enshrined in Article15 (1) of the Universal Declaration on Human Rights 
(Art. 15 UDHR). The basic presumption in international law on the nationality of persons with the nationality of the territories affected by state succession is that: "In the absence of agreement to the contrary, persons habitually resident in the territory of the new state automatically acquire the nationality of that state, for all international purpose, and lose their former nationality, but this is subject to a right in the new state to delimit more particularly who will be regarded as its nationals" (Manby, 2012).

All these point to the fact, that peace has not yet been achieved, therefore the following measures should be taken to overcome the challenges imposed by the citizenship question. First, forging Sudanese national identity means that there should be social relations of citizenship through social, economic and political equality as a matter of state policy. Second, racial prejudice is a product of social events; it must be destroyed through acquired national citizenship. This means certain measures should be adopted to help inculcate the value of social citizenship. Right of residence right should be adopted as one of the remedial measures to bring about peace and harmony between the two countries. Third, the barrier of visa requirement to enter either of the two countries should be cancelled for a period of ten years. This is to enable the two countries to establish institutions that will take care of those problems and allow tension to come down between the two countries. Applying the nationality laws at this level would rather aggravate the already tensed situation and further severe their relationship.

\section{Conclusion}

In conclusion, understanding the historical and materialistic context of the Sudanese state in relation to citizenship will help to sharpen the pattern of state-ethnic relations in the Arabsdominated political system. Any serious effort to resolve the citizenship question must be based on establishing the relationship between the citizens and the state in post-war Sudan. The identity issue should be seriously addressed if both the 'old' and the 'new' Sudan were to were to enjoy stability.

What underscores the challenges of the citizenship crisis in Sudan is the fact that despite the separation in 2011, it is uncertain that this will bring an end to Sudan's state-building crisis. Any critical mind knows that from the beginning of the peace process any critical mind knows that it was not inclusive enough in terms of addressing the problem of nationality and citizenship of the various ethnic groups resident in either the north or the south. The two main actors in the negotiation for peace and referendum-NCP and SPLM-have not agreed on several post-referendum issues. Critical components of those negotiations cover citizenship, Abyei, oil revenues, Nile water-sharing, and borders among others. Unless these issues are resolved tension will continue to mount between them. Any action of both the governments of North Sudan and South Sudan that citizens recognize as insensitive to the history of ethnic discord will automatically project ethnic bias. So, a nation-building project needs to focus on citizens themselves, seeking to cultivate a strong sense of national 
It Is Not Yet 'Uhuru': Overcoming the Challenges of Citizenship and Nationality Questions in Post-Separation Sudan and South Sudan

over tribal membership. Invariably, it is the lack of national citizenship of equal political, economic, social and cultural rights, and denial of duties and benefits that led to inter-group struggle and conflict over political power and distribution of public goods. The denial of individual rights in post-war Sudan will amount to denial of groups' rights and heighten loyalty to the ethnic group rather than the state. When there is competing loyalties, there has to be a clear choice of where one belongs.

\section{References}

Aluko, O. (2006). Ethnic conflicts and citizenship crises in the central region, Ibadan, Programme on Ethnic and Federal Studies (PEFS).

Assal, M. A. (2011). Nationality and citizenship questions in Sudan after the Southern Sudan referendum vote. Sudan Report, 1.

El-Battahani, A. (2009). Ideological expansionist movements versus historical indigenous rights in the Darfur Region of Sudan: From actual homicide to potential genocide. In Hassan, S.M., \& Ray, C.E. (Eds.), Darfur and the Crisis of Governance in Sudan: A Critical Reader, Ithaca and London: Cornell University Press.

Hendricks, C. (1997). The national question, ethnicity, and the state: Some insights on South Africa. In Nzongola-Natalaja, G., \& Lee, M.C. (Eds.). The state and democracy in Africa. Harare: AAPS Books.

Herbst, J. (2002). State and power in Africa: Comparative lessons in authority and control. New Jersey: Princeton University Press.

Jamieson, L.(2002). Theorising identity, nationality and citizenship: Implications for European citizenship identity. Sociologia, 34, C. 6. Retrieved from http://www. ed.ac.uk/social/youth/index.htm

Jok, M. J. (2007). Sudan: Race, religion, and violence, Oxford: One World.

Jok, M. (2011). Diversity, unity and nation- building in South Sudan. Special Report, United States Institute of Peace.

Kimenyi, M.S. (2012, June). Future engagement between South Sudan and the Republic of Sudan. South Sudan: One year after independence: Opportunities and obstacles for Africa's newest country. B/Africa, Growth Initiative at Brookings Institutions / Africa Growth Initiative.

Lesch, A. (1998). Sudan contested national identities, Bloomington and Indianapolis: Indiana University Press.

Manby, B. (2012). The right to a nationality and the secession of South Sudan: A commentary on the impact of the New Laws. The Open Society Initiative for Africa (OSIEA).

Mohamed, A. A. (2003). Shame culture and inter-group conflicts: Experience from Sudan. Journal of Cultural Studies, S. 1, 68-86.

Momoh, A. (2001) Even birds have a home: Explaining the pathologies of the citizenship question in Nigeria. Text of EMPARC's Seventh Annual Lecture held on Thursday November 15. 
Nnoli, O. (1978). Ethnic politics in Nigeria. Enugu: Fourth Dimension.

O’Brein, J. (2001). International law. London: Cavendish Publishing Limited.

Osaghae, E. E. (1990). The crisis of national identity in Africa: Clearing the conceptual under Bush. International Monthly Journal xix (2 and 3), 116-132, March. . (2002). Nigeria since independence crippled giant.Ibadan, Arches.

Pattie, C. et al. (2004). Citizenship in Britain: Values, participation and democracy, Cambridge: Cambridge University Press.

Prah, K. K. (2001). Race, discrimination, slavery, nationalism and citizenship in the AfroArabs borderlands: With particular reference to the Sudan. UNRISD.

Sikainga, A. A. (2011).Citizenship and identity in post-secession Northern Sudan, analysis and action on policies impacting Africa. Association of Concerned African Scholars.

Tadesse, D. (2012). Post-independence South Sudan: The challenges ahead. Isttuto Per Gli Studi Di Politica Internzionale (Ispi) Working Paper, No. 46, February. The African Charter on Human and Peoples' Rights.

Yoh, J. G. ( 2010). Power politics and Sudan's end game. The Africa organization. The Alternative Monthly Magazine of the Institute for Security Studies, 12-15.

Yousif, A., \& Rothbart, D. (2012). Sudan and South Sudan: Post-separation challenges, Retrieved from http://www.beyondintractability.org/casestudy/yousif-rothbartsudan-south-sudan 